Sains Malaysiana 46(7)(2017): 1097-1102

http://dx.doi.org/10.17576/jsm-2017-4607-12

\title{
Comparative Study of Poly(4-vinylpyridine) and Polylactic Acid-block-poly(2-vinylpyridine) Nanocomposites on Structural, Morphological and Electrochemical Properties
}

(Kajian Perbandingan Nanokomposit Poli(4-vinilpiridine) dan Polilaktik Asid-blok-poli(2-vinilpiridine) ke atas Sifat Struktur, Morfologi dan Elektrokimia)

\author{
JiAJIA LONG, AZLIN SUHAIDA AZMI, MinSOO P. KIM \& FATHILAH BINTI ALI*
}

\begin{abstract}
Polymer-based nanocomposites have attracted a lot of attention for amperometric biosensor development due to their general physical and chemical properties including biocompatibility, film-forming ability, stability and different functional groups that can be bonded with other biomolecues. In this study, poly-4-vinlyridine homopolymer (P4VP) and polylactic acid-block-poly(2-vinylpyridine) block copolymer (PLA-b-P2VP) were used to hybridize with gold precursors $\left(A u^{3+)}\right.$ based on the association between the nitrogen of the pyridine group of P4VP or P2VP block with gold precursors. $P 4 V P / A u^{3+}$ and PLA-b-P2VP/Au $u^{3+}$ nanocomposites were prepared with ratio of gold to P2VP or P4VP(10:1). The Au $u^{3+}$ in both polymers was reduced to gold nanoparticles (AuNPs) via in-situ approach by using hydrazine. Fourier transform infrared spectroscopy (FTIR), ultraviolet-visible spectroscopy (UV-vis), transmission electron microscopy (TEM) and cyclic voltammetry $(\mathrm{CV})$ were used to characterize the structural, morphological and electrochemical properties of the nanocomposites. The peak currents of P4VP/AuNPs and PLA-b-P2VP/AuNPs nanocomposites modified electrode were $6.685 \mathrm{nA}$ and $69.432 \mathrm{nA}$, respectively, which are much lower than bare electrode $(205.019 \mathrm{nA})$ due to the non-conductivity of P4VP and PLA-b-P2VP. In order to improve the electron transfer capability of electrode, graphene oxide (GO) was blended and electrochemically reduced to obtain P4VP/AuNPs/rGO and PLA-b-P2VP/AuNPs/rGO nanocomposites. After immobilization of these two nanocomposites on electrode through drop casting method, the peak currents of P4VP/AuNPs/ $r G O$ and PLA-b-P2VP/AuNPs/rGO nanocomposites modified electrode were $871.172 n A$ and $663.947 n A$, respectively, which are much higher than bare electrode (205.019 nA) and shown good capability to accelerate electron transfer. Based on these characterizations, P4VP/AuNPs/rGO has potential as the nanocomposite to modify the electrode for enzymatic biosensor development.
\end{abstract}

Keywords: Block copolymers; cyclic voltammetry; enzyme biosensor; graphene; Poly-4-vinlyridine

\section{ABSTRAK}

Nanokomposit polimer bagi pembangunan biosensor amperometrik menarik banyak perhatian kerana sifat fizikal dan kimia am mereka termasuk keserasian-bio, keupayaan pembentukan filem, kestabilan dan bergantung kepada kumpulan berfungsi yang berkemampuan untuk terikat dengan biomolekul lain. Dalam kajian ini, poli-4-vinilpiridin (P4VP) dan polilaktik asid-blok-poly (2-vinilpiridin) (PLA-b-P2VP) telah digunakan untuk dihibridkan dengan prekursor emas berdasarkan gabungan antara nitrogen kumpulan piridin daripada P4VP atau P2VP blok dengan prekursor emas (A $u^{3+)}$. Nanokomposit P4VP/Au ${ }^{3+}$ dan PLA-b-P2VP/Au ${ }^{3+}$ telah disediakan dengan nisbah emas kepada P2 VP atau P4VP (10:1). $P 4 V P / A u N P s$ dan PLA-b-P2VP/AuNPs nanokomposit telah disediakan melalui pendekatan in-situ dengan menggunakan hidrazin. Spektroskopi transformasi Fourier inframerah (FTIR), spektroskopi ultraviolet boleh dilihat (UV-vis), mikroskop elektron penghantaraan (TEM) dan voltammetri berkitar (CV) telah digunakan untuk mencirikan sifat struktur, morfologi dan elektrokimia nanokomposit tersebut. Arus puncak untuk bahan P4VP/AuNPs dan PLA-b-P2VP/AuNPs pengubah suai elektrod adalah 6.685 nA dan 69.432 nA, yang jauh lebih rendah daripada nilai elektrod (205.019 nA) disebabkan sifat tidak kekonduksian daripada P4VP dan PLA-b-P2VP. Dalam usaha untuk meningkatkan keupayaan pemindahan elektron elektrod, grafin oksida (GO) telah dicampurkan dan diperoleh dengan kaedah elektrokimia bagi penyediaan P4VP/AuNPs/rGO dan nanokomposit PLA-b-P2VP/AuNPs/rGO. Selepas proses immobilasi oleh bahan nanokomposit pada elektrod melalui teknik saliran titisan dengan puncak elektrod arus untuk P4VP/AuNPs/rGO dan PLA-b-P2VP/AuNPS/ rGO nanokomposit masing-masing diubah suai menunjukkan nilai 871.172 nA dan 663.947 nA. Nilai tersebut jauh lebih tinggi daripada permukaan elektrod (205.019 nA) serta menunjukkan kemampuan yang baik untuk mempercepatkan pemindahan elektron. Berdasarkan pencirian ini, P4VP/AuNPs/rGO mempunyai potensi sebagai komposit nano untuk mengubah suai elektrod bagi pembangunan enzim biosensor.

Kata kunci: Blok kopolimer; enzim biosensor; grafin; poli-4-viniliridine; voltammetri berkitar 


\section{INTRODUCTION}

It is widely acknowledged that nanomaterials-modified electrode of an enzymatic biosensor play an important part in improving the performance of biosensor. Biosensor provides an attractive means to detect and analyze the content of a biological sample such as glucose in microalgae and microbial culture. Gold nanopaticles (AuNPs) and polymers based nanocomposites are among nanomaterials that have gained considerable attention based on their excellent conductivity and catalytic properties. AuNPs introduce many advantages to electrochemical sensors, including their ability to provide biocompatibility and efficient loading sites for immobilizing enzymes and further improving electron transfer between the active site and electrode (Putzbach \& Ronkainen 2013). Certain properties of polymers, including stability, ease of synthesis, excellent tailorability, and good processability, also attracted many researchers' attention (Wang \& Uchiyama 2013). Vinyl pyridines such as P2VP and P4VP are an important class of synthetic polymer that attract many attentions due to the nitrogen atom in the aromatic ring (Özyalçin et al. 1997). Poly(4-vinylpyridine) (P4VP) as a synthetic water soluble polymer and coordinative reagent for transition metals has been paid much attention in recent years, which is often used to extract heavy metals in waste water treatment and also as a host ligand of metal-containing chromospheres (Li et al. 2008, 2007). P4VP and P2VP are also frequently co-polymerized with other polymer for block copolymers (BCPs) synthesis which made up of blocks of different polymerized monomers, where they are linked by a covalent bond at their ends (Ku et al. 2014). BCPs made of blocks of different polymerized monomers linked by covalent bonds at their ends likewise attracted interest based on their structure, size and chemical composition. Self-assembly of BCPS can generate nanostructured particles with tunable internal structures, shapes and surface properties, which provide potential application in particle-based technology (Smart et al. 2008).

The polymer chains grafted/coated on the surfaces of AuNPs not only enhance the stability of gold cores intensively, but also functionalize the gold core due to the special properties of outside polymer layers (Li et al. 2009). Furthermore, it is well acknowledged that incorporating nanoparticles into a polymer matrix can have a significant influence in the properties of the binding matrix, including mechanical strength, conductivity, permeability and catalytic activities (Chiu et al. 2005). Normally, metal nanoparticles/polymer nanocomposites can be synthesized through ex-situ and in-situ approaches. In the ex-situ approach, metal nanoparticles are first produced by soft-chemistry routes and then dispersed into polymeric matrices, while for in-situ approach, metal nanoparticles are generated inside a polymer matrix through chemical reduction of a metallic precursor dissolved into the polymer (Kim \& Yi 2015; Sarkar et al. 2012).

Over the past few years, graphene attracted a lot of attention due to its one-atom-thick planar sheet of $\mathrm{sp}^{2}$ bonded carbon atoms that are densely arranged into a 2D honeycomb-structure with superior electrical conductivity, excellent chemical stability and high surface to volume ratio (Pumera 2011). Its ability for facilitating electron transfer, excellent biocompatibility, large specific surface and low cost make graphene an ideal material for the construction of sensors and biosensor-based devices in various transduction modes, from electrical and electrochemical transduction to optical transduction (Dreyer et al. 2010; Pumera 2011). The electrochemical reduction of graphene oxide (GO) to produce reduced graphene oxide ( $\mathrm{rGO}$ ) was frequently applied in graphene based nanocomposites (Pei \& Cheng 2012; Unnikrishnan et al. 2013).

To the best of our knowledge, no study has been conducted to utilize the P4VP homopolymer and PLA-bP2VP block copolymer for enzymatic biosensor, in which the preliminary research towards the application should be conducted. In this research, polylactic acid (PLA)-blockpoly(2-vinylpyridine) (P2VP) (PLA-b-P2VP) and poly4-vinlyridine (P4VP) were used for hybridization with $\mathrm{Au}^{3+}$ by taking advantages of the association between the long-pair nitrogen of the pyridine and various metal irons (Lin et al.2010). The in-situ synthesis of gold nanoparticles in BCP and P4VP was accomplished via in-situ synthesis by using hydrazine hydrates as reducing reagent and characterized through FTIR, UV-vis, TEM and CV. After blending with GO, BCP/AuNPs/GO and P4VP/AuNPs/GO nanocomposites were electrochemical reduced in order to prepare $\mathrm{BCP} / \mathrm{AuNPs} / \mathrm{rGO}$ and $\mathrm{P} 4 \mathrm{VP} / \mathrm{AuNPs} / \mathrm{rGO}$ for electrode modification and characterized through $\mathrm{CV}$.

\section{MATERIALS AND METHODS}

\section{REAGENTS AND APPARATUS}

Polylactic acid-block-poly(2-vinylpyridine) (PLA-b-P2VP) with molecular weight $\left(\mathrm{M}_{\mathrm{w}}\right) 38400 \mathrm{~g} \mathrm{~mol}^{-1}$ and $f_{P L A}=$ 0.36 , poly-4-vinlyridine ( $\mathrm{P} 4 \mathrm{VP})$ with molecular weight $\left(\mathrm{M}_{\mathrm{w}}\right) 24000 \mathrm{~g} \mathrm{~mol}^{-1}$ was synthesized and obtained from Polymer Nano Electronics Laboratory, KAIST, South Korea. Gold (III) chloride trihydrate ( $\geq 99.9 \%$ trace metals basis, $\mathrm{HAuCl}_{4} \cdot 3 \mathrm{H}_{2} \mathrm{O}$ ), hydrazine solution ( 35 wt. $\%$ in $\mathrm{H}_{2} \mathrm{O}$, $\left.\mathrm{N}_{2} \mathrm{H}_{4} \cdot \mathrm{H}_{2} \mathrm{O}\right)$ and dichloromethane $\left(\mathrm{CH}_{2} \mathrm{Cl}_{2}\right.$, anhydrous, $\geq 99.8 \%$ ) were all purchased from Sigma-Aldrich. Potassium ferricyanide $\left(\mathrm{K}_{3} \mathrm{Fe}(\mathrm{CN})_{6}\right)$ was purchased from R\&M Chemicals, Selangor, Malaysia.

All electrochemical experiments to characterize BCP/ AuNP, composites were performed using a conventional three-electrode cell and a pocketSTAT (IVIUM Technologies, Eindhoven, Netherlands) as potentiostat/galvanostat/ impedance analyzer. A modified glassy carbon electrode (GCE, inner diameter of $3.0 \mathrm{~mm}$ ) was used as the working electrode (WE), platinum (Pt) was used as the counter electrode (CE) and silver/silver chloride $(\mathrm{Ag} / \mathrm{AgCl})$ in $3.0 \mathrm{M}$ saturated sodium chloride $(\mathrm{NaCl})$ was used as the reference electrode (RE).All electrodes were purchased from ALS Co., 
Ltd., Tokyo, Japan. Prior to surface modifications, the GCE was polished with diamond $(0.1 \mu \mathrm{m})$ and alumina slurry $(0.05 \mu \mathrm{m})$ purchased from ALs Co., Ltd., Tokyo, Japan, ultrasonicated in ethanol for $1 \mathrm{~min}$ followed by deionized (DI) water for $1 \mathrm{~min}$ and then dried in a desiccator for 30 min before use. UV-vis spectroscopy measurements (350$650 \mathrm{~nm}$ ) were performed using UviLine 9400 (SECOMAN, France) at room temperature with a $10 \mathrm{~mm}$ optical length quartz cuvette. The Fourier transform infrared spectroscopy (FTIR) investigations were carried out with the Nicolet iS50 FT-IR Spectrometer (Thermal Scientific, USA). The morphology of nanocomposites was characterized via Transmission Electron Microscopy (JEOL JEM-2100 using an accelerating voltage of $200 \mathrm{kV}$ ). For phosphate buffer solution preparation, sodium phosphate dibasic heptahydrate $\left(\mathrm{Na}_{2} \mathrm{HPO}_{4} \cdot 7 \mathrm{H}_{2} \mathrm{O}\right)$, sodium phosphate dibasic $\left(\mathrm{Na}_{2} \mathrm{HPO}_{4}\right)$, sodium phosphate monobasic $\left(\mathrm{NaH}_{2} \mathrm{PO}_{4}\right)$ and potassium phosphate monobasic $\left(\mathrm{KH}_{2} \mathrm{PO}_{4}\right)$ were purchased from Sigma-Aldrich. Potassium chloride $(\mathrm{KCl})$, potassium ferricyanide $\left(\mathrm{K}_{3} \mathrm{Fe}(\mathrm{CN})_{6}\right)$ and sodium chloride $(\mathrm{NaCl})$ were obtained from R\&M, Chemicals, Selangor, Malaysia. Distilled water (DI) water obtained from ultrapure water purification system (SARTORIUS, Arium 611) was used throughout all experiments.

\section{HYBRIDIZATION OF GOLD PRECURSORS WITH POLYMERS}

A 5 wt. \% of BCP (PLA-b-P2VP) solution and 5 wt. \% $\mathrm{P} 4 \mathrm{VP}$ were separately prepared in dichloromethane (DCM) and ethanol solutions, stirred for $14 \mathrm{~h}$. The $\mathrm{BCP} / \mathrm{Au}^{3+}$ and $\mathrm{P} 4 \mathrm{VP} / \mathrm{Au}^{3+}$ nanocomposite were prepared based on the specific mole ratio $\left(\mathrm{Au}^{3+}: \mathrm{BCP}=10: 1\right.$ and $\mathrm{Au}^{3+}: \mathrm{P} 4 \mathrm{VP}$ $=10: 1)$ through $24 \mathrm{~h}$ stirring. $\mathrm{BCP} / \mathrm{Au}^{3+}$ and $\mathrm{P} 4 \mathrm{VP} / \mathrm{Au}^{3+}$ nanocomposites and control (BCP in DCM, P4VP in ethanol) were characterized via FTIR for investigation of association between the nitrogen of pyridine group and $\mathrm{Au}^{3+}$.

\section{IN-SITU SYNTHESIS OF GOLD NANOPARTICLES}

AuNPs in P4VP and BCP were in-situ synthesized using hydrazine hydrate $\left(\mathrm{N}_{2} \mathrm{H}_{4} \bullet \mathrm{H} 2 \mathrm{O}\right)$ reduction method. The color of the $\mathrm{Au}^{3+} /$ polymer solutions changed from yellow to purple after addition of $\mathrm{N}_{2} \mathrm{H}_{4}$. The formation of nanoparticles is confirmed by UV-vis spectroscopy where the peak is formed within the measurement range.

\section{CHARACTERIZATION OF BCP/AUNPS AND P4VP/AUNPS NANOCOMPOSITES}

The Fourier transform infrared spectroscopy (FTIR) investigations were carried out with the Nicolet iS50 FT-IR Spectrometer (Thermal Scientific, USA). UVvis spectroscopy measurements $(350-650 \mathrm{~nm})$ were performed using UviLine 9400 (SECOMAN, France) at room temperature with a $10 \mathrm{~mm}$ optical length quartz cuvette. The morphology of nanocomposites was characterized via Transmission Electron Microscopy (JEOL JEM-2100 using an accelerating voltage of $200 \mathrm{kV}$ ). Cyclic voltammetry (CV) was performed to evaluate the electron-transfer capabilities of the modified layer based on the oxidation peak current in $0.05 \mathrm{M}$ potassium ferricyanide $\left(\mathrm{K}_{3} \mathrm{Fe}(\mathrm{CN})_{6}\right)$ solution at a scan rate of $50 \mathrm{mV} / \mathrm{s}$.

\section{PREPARATION AND CHARACTERIZATION OF BCP/AUNPS/ GRAPHENE AND P4VP/AUNPS/GRAPHENE COMPOSITES}

GO was blended into these two nanocomposites based on 1:1 ratio of GO: BCP/AuNPs or P4VP/AuNPs. After 30 cycles of electrochemical reduction in $0.01 \mathrm{M}$ PBS $(\mathrm{pH}$ 5), the resulting $\mathrm{BCP} / \mathrm{AuNPs} / \mathrm{rGO}$ and $\mathrm{P} 4 \mathrm{VP} / \mathrm{AuNPs} / \mathrm{rGO}$ nanocomposites were characterized via $\mathrm{CV}$ in order to evaluate the electron-transfer capabilities of the modified layer on electrode.

\section{RESULTS AND DISCUSSION}

Figure 1 shows FTIR spectrum of $\mathrm{BCP}, \mathrm{BCP} / \mathrm{Au}^{3+}$ and $\mathrm{BCP} /$ AuNPs nanocomposite. The two peaks at 1435 and 1473 $\mathrm{cm}^{-1}$ were attributed to $\mathrm{C}-\mathrm{C}$ stretching of the pyridine ring. The peak at $1753 \mathrm{~cm}^{-1}$ was related to the $\mathrm{C}=\mathrm{O}$ stretching of PLA block (Yuen et al. 2005). Another two peaks from 1550 to $1600 \mathrm{~cm}^{-1}$ were related to $\mathrm{C}=\mathrm{N}$ stretching of the pyridine group. Whereas, FTIR spectrum of P4VP, P4VP/ $\mathrm{Au}^{3+}$ and P4VP/AuNPs nanocomposites is shown in Figure 2. The two peaks around 1418 and $1451 \mathrm{~cm}^{-1}$ were attributed to $\mathrm{C}-\mathrm{C}$ stretching of the pyridine ring (Yuen et al. 2005). Another two peaks from 1600 to $1700 \mathrm{~cm}^{-1}$ were also related to $\mathrm{C}=\mathrm{N}$ stretching of the pyridine group.

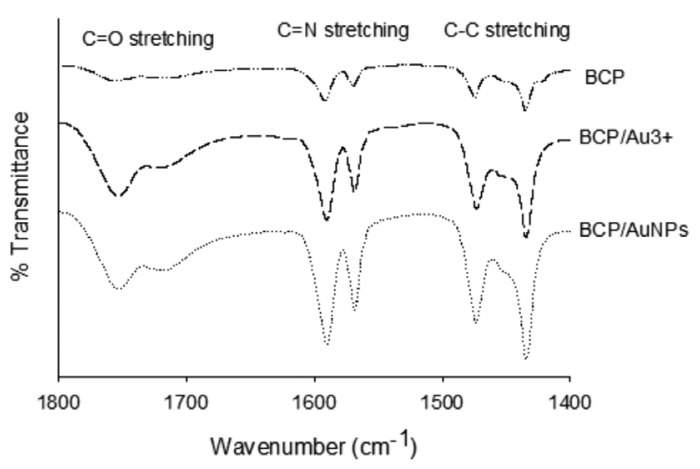

FIGURE 1. FTIR spectrum of $\mathrm{BCP}, \mathrm{BCP} / \mathrm{Au}^{3+}, \mathrm{BCP} / \mathrm{AuNPS}$ composites in the range from 1400 to $1800 \mathrm{~cm}^{-1}$

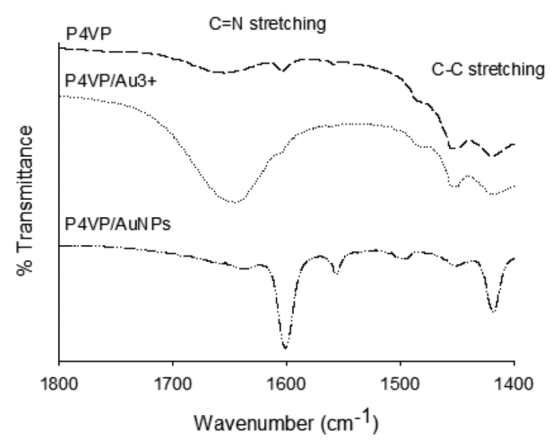

FIGURE 2. FTIR spectrum of P4VP, P4VP/Au ${ }^{3+}$, P4VP/AuNPs composites in the range from 1400 to $1800 \mathrm{~cm}^{-1}$ 
Table 1 summarized the comparison of $\mathrm{C}=\mathrm{N}$ stretching between $\mathrm{BCP}$ and $\mathrm{P} 4 \mathrm{VP}$ related nanoparticles. The wavenumber of $\mathrm{C}=\mathrm{N}$ stretching of $\mathrm{BCP} / \mathrm{Au}^{3+}$ was shifted to 1569 and $1590 \mathrm{~cm}^{-1}$ from 1570 and $1592 \mathrm{~cm}^{-1}$ of BCP, respectively. On the other hand, there is no shift of wavenumber for $\mathrm{BCP} / \mathrm{Au}^{3+}$ into $\mathrm{BCP} / \mathrm{AuNPs}$ nancomposites. The wavenumber of $\mathrm{C}=\mathrm{N}$ stretching of $\mathrm{P} 4 \mathrm{VP} / \mathrm{Au}^{3+}$ however was slightly shifted to $1652 \mathrm{~cm}^{-1}$ from $1653 \mathrm{~cm}^{-1}$ of P4VP. On the other hand, slight shift were observed for P4VP/ $\mathrm{Au}^{3+}$ and P4VP/AuNPs nanocomposites from 1604 and $1652 \mathrm{~cm}^{-1}$ to 1602 and $1651 \mathrm{~cm}^{-1}$, respectively. This blue shift (decrease in wavelength) is important to study the hybridization between $\mathrm{Au}^{3+}$ and pyridine groups from P2VP block. The shift attributes to the association of the gold precursors with the long pair nitrogen of $\mathrm{P} 2 \mathrm{VP}$ which cause the increase of binding energy associated with $\mathrm{C}=\mathrm{N}$ stretching (Lin et al. 2010). In addition, the blue shift of $\mathrm{P} 4 \mathrm{VP}$ with gold precursors is slightly stronger than that of BCP which could be related to the different arrange of pyridine groups from P2VP block and P4VP.

After in-situ synthesis of AuNPs in $\mathrm{Au}^{3+} /$ polymers nanocomposites by using hydrazine, the characteristic plasmon resonance absorption band for AuNPs occurred between 500 and $600 \mathrm{~nm}$ in the visible region of the electromagnetic spectrum, in which confirmed the formation of nanoparticles in these two nanocomposites

TABLE 1. The comparison of $\mathrm{C}=\mathrm{N}$ stretching of $\mathrm{BCP}$ and $\mathrm{P} 4 \mathrm{VP}$ related nanocomposites

\begin{tabular}{lc}
\hline Samples & $\begin{array}{c}\text { Wavenumber of } \mathrm{C}=\mathrm{N} \text { stretching } \\
\text { from pyridine group }\left(\mathrm{cm}^{-1}\right)\end{array}$ \\
\hline $\mathrm{BCP}$ & 1570,1592 \\
$\mathrm{BCP} / \mathrm{Au}^{3+}$ & 1569,1590 \\
$\mathrm{BCP} / \mathrm{AuNPs}^{3}$ & 1569,1590 \\
$\mathrm{P} 4 \mathrm{VP}$ & 1604,1653 \\
$\mathrm{P} 4 \mathrm{VP} / \mathrm{Au}^{3+}$ & 1604,1652 \\
$\mathrm{P} 4 \mathrm{VP} / \mathrm{AuNPs}^{3+}$ & 1602,1651 \\
\hline
\end{tabular}

(Johan et al. 2012). The successful synthesis of gold nanoparticles through hydrazine reduction of $\mathrm{HAuCl}_{4}$. $3 \mathrm{H}_{2} \mathrm{O}$ was proved via UV-vis spectra.

Based on Figure 3, the wavelength of peak AuNPs absorbance in BCP was 536 and $548 \mathrm{~nm}$ of P4VP, which indicate the size of AuNPs in P4VP was larger than AuNPs in BCP (Sasha \& Hadi 2008). This result was confirmed through TEM images as shown in Figure 4. The dark spots were AuNPs and the bright parts were polymer (BCP or P4VP). TEM study of AuNPs in BCP and P4VP confirmed that the particles are almost spherical in shape with size ranging from 10 to $40 \mathrm{~nm}$ (BCP) and 10 to $70 \mathrm{~nm}$ (P4VP).

The electrochemical properties of the BCP/AuNPs and P4VP/AuNPs nanocomposites were identified through CV. Figure 5 shows CVs of bare GCE and GCE modified with BCP/ AuNPs, P4VP/AuNPs nanocomposites. The peak currents of BCP/AuNPs $(69.432 \mu \mathrm{A})$ and P4VP/AuNPs $(6.685 \mu \mathrm{A})$ modified GCE were much lower than that for a bare GCE $(205.019 \mu \mathrm{A})$ owing to the non-conductive property of the $\mathrm{BCP}$ and P4VP.

In order to improve the conductivity of the modified layer on the GCE and accelerate electron transfer, highly conductive reduced graphene oxide was introduced to prepare $\mathrm{BCP} / \mathrm{AuNPs} / \mathrm{rGO}$ and $\mathrm{P} 4 \mathrm{VP} / \mathrm{AuNPs} / \mathrm{rGO}$ nanocomposites. After blending GO with $\mathrm{BCP} / \mathrm{AuNPs}$ and

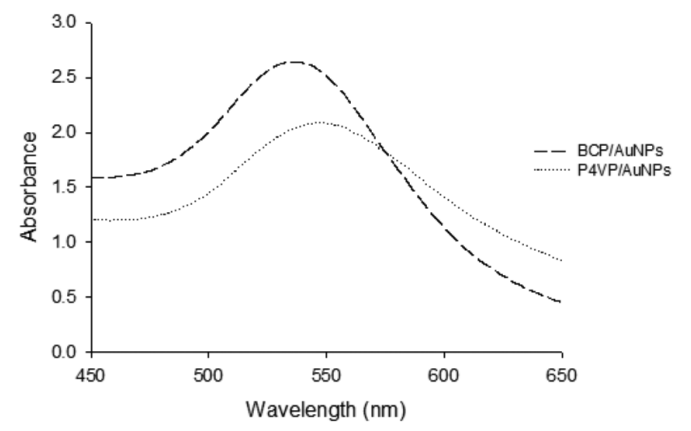

FIGURE 3. UV-vis spectrum of BCP/AuNPs, P4VP/AuNPs composites in the range between 450 and $650 \mathrm{~nm}$

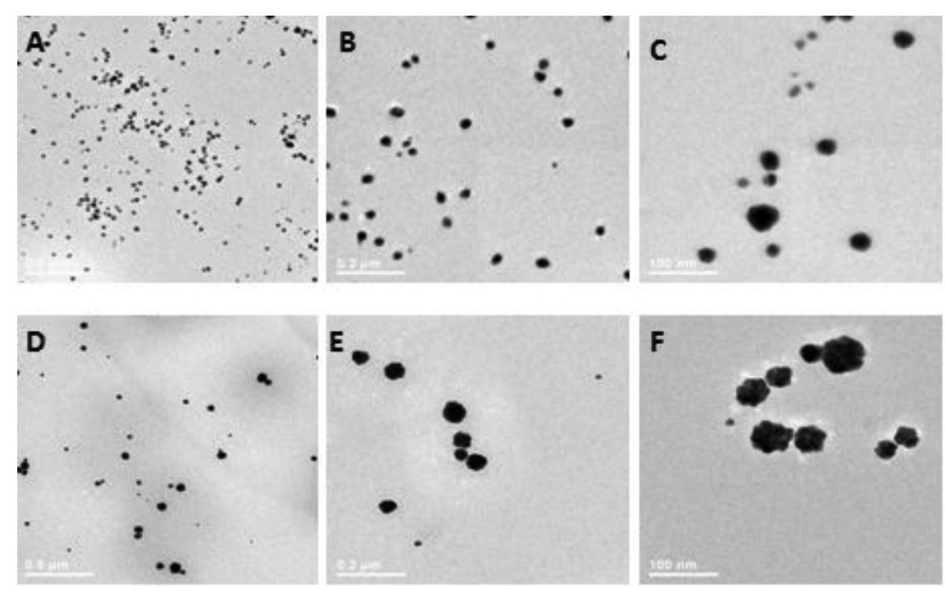

FIGURE 4. TEM images of BCP/AuNPs (A, B , C) and P4VP/AuNPs composites (D, E, F): A and D: $0.5 \mathrm{um}, \mathrm{B}$ and E: $0.2 \mathrm{um}, \mathrm{C}$ and F: $100 \mathrm{~nm}$ 


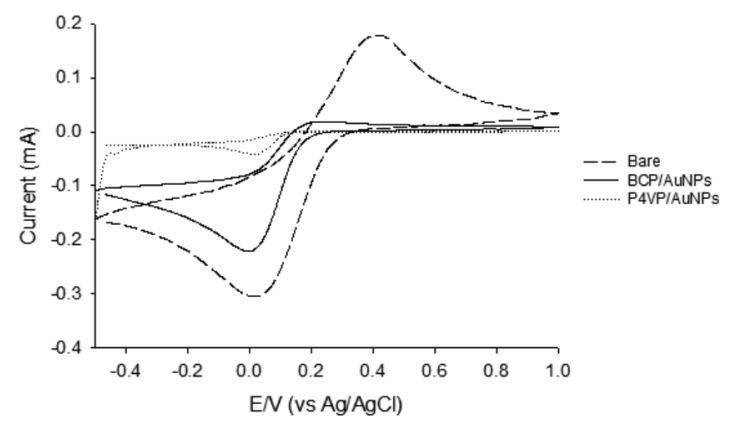

FIGURE 5. CVs of bare GCE, and GCEs modified with BCP/ AuNPs and P4VP/AuNPs nanocomposites in $0.05 \mathrm{M}$ $\mathrm{K}_{3} \mathrm{Fe}(\mathrm{CN})_{6}$ solution at a scan rate of $50 \mathrm{mV} / \mathrm{s}$

P4VP/AuNPs, electrochemical reduction was applied to reduce GO to rGO in 0.01 M PBS (pH5) (Pei \& Cheng 2012). The electrochemical properties of the $\mathrm{BCP} / \mathrm{AuNPs} / \mathrm{rGO}$ and $\mathrm{P} 4 \mathrm{VP} / \mathrm{AuNP} / \mathrm{rGO}$ nanocomposites were identified through CV, which is shown in Figure 6. The peak currents of bare GCE, BCP/AuNPs/rGO and P4VP/AuNPs/rGO were at 205.019 $\mu \mathrm{A}, 663.947 \mu \mathrm{A}$ and $871.172 \mu \mathrm{A}$, respectively. This indicates that the high conductivity of P4VP/AuNPs/ rGO has potential to be used as transducer modification and enzyme immobilization for enzymatic biosensor.

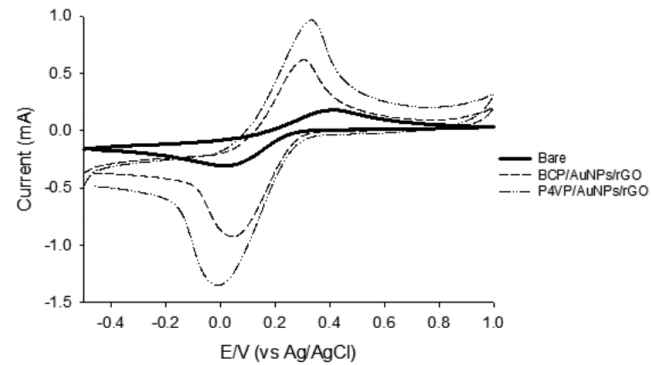

FIGURE 6. CVs of BCP/AuNPs/rGO and P4VP/AuNPs/rGO composites in $0.05 \mathrm{M} \mathrm{K}_{3} \mathrm{Fe}(\mathrm{CN})_{6}$ solution at a scan rate of $50 \mathrm{mV} / \mathrm{s}$

\section{CONCLUSION AND FUTURE WORK}

In this research, the comparative study of P4VP/AuNPs and PLA-b-P2VP/AuNPs nanocomposites on structural, morphological and electrochemical properties were accomplished. After adding graphene and electrochemical reduction, the conductivity and ability for electron transfer of $\mathrm{BCP} / \mathrm{AuNP} / \mathrm{rGO}$ and $\mathrm{P} 4 \mathrm{VP} / \mathrm{AuNPs} / \mathrm{rGO}$ nanocomposites was improved and $\mathrm{P} 4 \mathrm{VP} / \mathrm{AuNPs} / \mathrm{rGO}$ will be selected as the optimum nanocomposite to modify the electrode for further enzymatic biosensor research. These nanocomposites have potential to be used for the targeted application.

\section{ACKNOWLEDGEMENTS}

The authors thanked International Institute for Halal Research and Training (INHART Lab) of IIUM for FTIR analysis assistance, Polymer Nanoelectronics Laboratory in Korea Advanced Institute of Science and Technology (KAIST) for polymers synthesis. This work is funded under the IIUM Research Initiative Grant (Ref: RIGS16-089-0253) and Fundamental Research Grant Scheme (FRGS14-1050346) from the Ministry of Higher Education (MOHE), Malaysia.

\section{REFERENCES}

Chiu, J.J., Kim, B.J., Kramer, E.J. \& Pine, D.J. 2005. Control of nanoparticle location in block copolymers. Journal of the American Chemical Society 127(14): 5036-5037.

Dreyer, D.R., Park, S., Bielawski, C.W. \& Ruoff, R.S. 2010. The chemistry of graphene oxide. Chemical Society Reviews 39(1): 228-240

Johan, Mohd Rafie, Chong, L.C. \& Hamizi, N.A. 2012. Preparation and stabilization of monodisperse colloidal gold by reduction with monosodium glutamate and poly (methyl methacrylate). Int. J. Electrochem. Sci. 7: 4567-4573.

Kim, M.P. \& Yi, G-R. 2015. Nanostructured colloidal particles by confined self-assembly of block copolymers in evaporative droplets. Frontiers in Materials 2: 45.

Ku, K.H., Shin, J.M., Kim, M.P., Lee, C-H., Seo, M-K., Yi, G-R., Jang, S.G. \& Kim, B.J. 2014. Size-controlled nanoparticleguided assembly of block copolymers for convex lens-shaped particles. Journal of the American Chemical Society 136(28): 9982-9989.

Li, D., He, Q. \& Li, J. 2009. Smart core/shell nanocomposites: Intelligent polymers modified gold nanoparticles. Advances in Colloid and Interface Science 149(1): 28-38.

Li, D., He, Q., Yang, Y., Helmuth, M. \& Li, J. 2008. Two-stage pH response of poly (4-vinylpyridine) grafted gold nanoparticles. Macromolecules 41(19): 7254-7256.

Li, D., He, Q., Cui, Y. \& Li, J. 2007. Fabrication of pH-responsive nanocomposites of gold nanoparticles/poly (4-vinylpyridine). Chemistry of Materials 19(3): 412-417.

Lin, T., Li, C-L., Ho, R-M. \& Ho, J-C. 2010. Association strength of metal ions with poly (4-vinylpyridine) in inorganic/ poly (4-vinylpyridine)-b-poly ( $\varepsilon$-caprolactone) hybrids. Macromolecules 43(7): 3383-3391.

Sasha Md Nasir \& Hadi Nur. 2008. Gold nanoparticles embedded on the surface of polyvinyl alcohol layer. Journal of Fundamental Sciences 4: 245-252.

Özyalçin, M., Küçükyavuz, Z., Jarvaherian, A. \& Küçükyavuz, S. 1997. Electrical conductivity of sodium doped poly (4-vinylpyridine). Turkish Journal of Chemistry 21(4): 296-299.

Pei, S. \& Cheng, H-M. 2012. The reduction of graphene oxide. Carbon 50(9): 3210-3228.

Pumera, M. 2011. Graphene in biosensing. Materials Today 14(7): 308-315.

Putzbach, W. \& Ronkainen, N.J. 2013. Immobilization techniques in the fabrication of nanomaterial-based electrochemical biosensors: A review. Sensors 13(4): 4811-4840.

Sarkar, S., Guibal, E., Quignard, F. \& SenGupta, A.K. 2012. Polymer-supported metals and metal oxide nanoparticles: Synthesis, characterization, and applications. Journal of Nanoparticle Research 14(2): 1-24.

Smart, T., Lomas, H., Massignani, M., Flores-Merino, M.V., Perez, L.R. \& Battaglia, G. 2008. Block copolymer nanostructures. Nano Today 3(3): 38-46. 
Unnikrishnan, B., Palanisamy, S. \& Chen, S-M. 2013. A simple electrochemical approach to fabricate a glucose biosensor based on graphene-glucose oxidase biocomposite. Biosensors and Bioelectronics 39(1): 70-75.

Wang, X. \& Uchiyama, S. 2013. Polymers for Biosensors Construction: INTECH Open Access Publisher.

Yuen, C.W.M., Ku, S.K.A., Choi, P.S.R., Kan, C.W. \& Tsang, S.Y. 2005. Determining functional groups of commercially available ink-jet printing reactive dyes using infrared spectroscopy. Research Journal of Textile and Apparel 9(2): 26-38.

Jiajia Long, Azlin Suhaida Azmi \& Fathilah Binti Ali* Department of Biotechnology Engineering,

Kulliyyah of Engineering

International Islamic University Malaysia, P.O. Box 10 50728 Kuala Lumpur, Federal Territory

Malaysia
Minsoo P. Kim

Ulsan National Institute of Science and Technology (UNIST) 50 UNIST-gil, Ulsan 44919

South Korea

*Corresponding author; email: fathilah@iium.edu.my

Received: 26 December 2016

Accepted: 6 March 2017 